\title{
Uji Coba Empat Varietas Kedelai di Kawasan Pesisir Berbasis Biokompos
}

\author{
YUDHI HARINI BERTHAM ${ }^{1}$, NUR AINI ${ }^{2}$, BAMBANG GONGGO MURCITRO $^{1}$, \\ ABIMANYU DIPO NUSANTARA ${ }^{1}$ \\ ${ }^{1}$ Program Studi Ilmu Tanah, Fakultas Pertanian, Universitas Bengkulu \\ Jl. Raya W.R. Supratman, Kandanglimun, Bengkulu. 38371 \\ Email: yudhyhb@unib.ac.id; bgonggo@unib.ac.id; abimanyu@unib.ac.id \\ ${ }^{2}$ Program Studi Agroekoteknologi, Fakultas Pertanian, Universitas Bengkulu \\ Jl. Raya W.R. Supratman, Kandanglimun, Bengkulu. 38371 \\ Email: naini@unib.ac.id
}

Received 17 January 2018; Received in revised form 29 January 2018;

Accepted 24 February 2018; Available online 9 May 2018

\begin{abstract}
This study aims to obtain soybean varieties that are able to grow well and produce high in biocomposite coastal areas. This study was compiled using Randomized Block Design (RAKL) with single factor consisting of four varieties of soybeans namely Wilis, Grobogan, Detam I and Detam II. The results showed that the varieties of Wilis produce the highest plant height $63,13 \mathrm{~cm}$, the highest percentage of pods per plant is $91,12 \%$, the highest number of seeds per plant is 249,56 pieces, the heaviest seed weight per plant is 30,92 gram, while the Grobogan which produce the heaviest dry weight is $7,92 \mathrm{~g}$, the highest $\mathrm{K}$ absorption is $0,22 \mathrm{~g}$ and the highest 100 seed weight is $18,00 \mathrm{~g}$. Thus, the varieties of Wilis and Grobogan have higher adaptation rates than the Detam 1 and Detam II varieties, which has the potential to be developed in coastal areas.
\end{abstract}

Keywords: biocompos, coastal land, soybean varieties

\section{INTISARI}

Penelitian ini bertujuan untuk mendapatkan varietas kedelai yang mampu tumbuh baik dan berproduksi tinggi di lahan pesisir yang diberi biokompos. Penelitian ini disusun menggunakan Rancangan Acak Kelompok Lengkap (RAKL) dengan faktor tunggal yang terdiri dari empat varietas kedelai yaitu Wilis, Grobogan, Detam I dan Detam II. Hasil penelitian menunjukkan bahwa varietas Wilis menghasilkan tinggi tanaman tertinggi yaitu $63,13 \mathrm{~cm}$, persentase polong bernas per tanaman tertinggi yaitu $91,12 \%$, jumlah biji per tanaman terbanyak yaitu 249,56 buah, dan bobot biji per tanaman terberat yaitu 30,92 g. Sedangkan Grobogan yang menghasilkan bobot kering tanaman terberat yaitu 7,92 g, serapan $\mathrm{K}$ tertinggi yaitu $0,22 \mathrm{~g}$ dan bobot 100 biji tertinggi yaitu 18,00 g. Dengan demikian, varietas Wilis dan Grobogan memiliki tingkat adaptasi lebih tinggi dibanding varietas Detam I dan Detam II, sehingga berpotensi untuk dikembangkan di kawasan pesisir.

Kata kunci: biokompos, lahan pesisir, varietas kedelai

\section{PENDAHULUAN}

Tanaman kedelai (Glycine max L.) merupakan tanaman pangan terpenting ketiga setelah padi dan jagung. Kedelai mengandung protein nabati yang sangat penting untuk meningkatkan gizi masyarakat Indonesia. Tanaman ini berpotensi untuk dikembangkan karena permintaannya yang terus meningkat setiap tahunnya seiring dengan bertambahnya jumlah penduduk dan juga kebutuhan bahan industri olahan pangan (Simarmata dan Sukiman, 2015; Barus, 2013). Produksi kedelai Indonesia dari tahun 2014-2015 sebesar 954,997 ton dan 982,967 ton dengan produktivitas yang meningkat dari 15,51 kuintal/ha menjadi 15,69 kuintal/ha dengan penurunan luas panen dari 615,685 ha menjadi 613,886 ha. Sedangkan angka impor kedelai 
yang dilakukan Indonesia mencapai 1,525,748 ton pada periode Januari sampai Agustus 2015. Di Bengkulu sendiri pada tahun 2014-2015 produksi kedelai mencapai 5,715 ton dan 5,388 ton dengan produktivitas $10,63 \mathrm{kuintal} / \mathrm{ha}$ dan 12,72 kuintal/ha (Kementerian Pertanian, 2015).

Salah satu cara untuk menambah luasan lahan adalah dengan memanfaatkan lahan marginal seperti lahan pesisir. Dengan panjang garis pantai mencapai $95,161 \mathrm{~km}$ dan luas lahan 1,060,000 ha, Indonesia menjadi prospek yang baik untuk budidaya pengembangan pertanian (Lasabuda, 2013; Yuwono, 2009). Panjang garis pantai Bengkulu tegas dan mencapai $\pm 525 \mathrm{~km}$ (Pemerintah Provinsi Bengkulu, 2015). Lahan pesisir umumnya mempunyai sifat tanah yang tidak stabil, lengas tanah rendah, evapotranspirasi tinggi, kandungan garam tinggi, dan rendah kandungan bahan organik (Sumardi, 2008; Shi et al, 2005). Kapasitas Tukar Kation (KTK), $\mathrm{C}$-organik dan $\mathrm{Ca}$ yang sangat rendah, daya mengikat air rendah (Rajiman $d k k ., 2008$ ), kekurangan unsur nitrogen (Sunardi dan Sarjono, 2007; Cornell et al., 2003), serta luas permukaan yang kecil dan pori yang besar (Sitorus dkk., 2008) yang menyebabkan kapasitas menahan air menjadi rendah. Hal tersebut menyebabkan media cepat kehilangan air dan kelembaban media menurun.

Penggunaan kompos dari kulit kopi diharapkan meningkatkan pertumbuhan dan hasil kedelai. Mellawati (2002) melaporkan bahwa kompos yang mengandung campuran kotoran sapi dan limbah kopi dapat menghasilkan kompos organik dengan struktur yang baik. Hasil penelitian Berlian $d k k$. (2015) menunjukkan bahwa penambahan kompos kulit kopi mampu meningkatkan pertumbuhan dan perkembangan tanaman cabai keriting (Capsicum annum L.) pada parameter tinggi tanaman, jumlah daun, jumlah buah dan berat buah cabai keriting. Sedangkan hasil penelitian Simanjuntak (2012) dan Sahputra $d k k$. (2013) bahwa pemberian kompos kulit kopi berpengaruh nyata terhadap peningkatan produksi bawang merah per plot.

Wirnas dkk. (2006) juga melaporkan bahwa pengembangan varietas berdaya hasil tinggi serta adaptif terhadap lingkungan bercekaman diharapkan meningkatkan produktivitas kedelai. Tetapi untuk memperoleh tanaman kedelai yang mempunyai produksi yang tinggi perlu diketahui varietas kedelai yang sesuai terhadap kondisi cekaman lingkungan yang ada. Varietas berperan penting dalam produksi kedelai karena untuk mencapai hasil yang tinggi sangat ditentukan oleh potensi genetiknya dan lingkungan tumbuhnya (Caldwell et al., 2005; Hartman et al., 2011). Jika pengelolaan lingkungan tumbuh tidak dilakukan dengan baik, maka potensi yang tinggi dari varietas unggulan juga tidak akan terwujud.

Varietas Grobogan berasal dari pemurnian populasi Lokal Malabar Grobogan. Varietas ini dilepas pada tahun 2008 dengan umur panen sekitar 76 hari dan potensi hasil mencapai 3,40 ton/ha serta polong masak yang tidak mudah pecah. Varietas Wilis memiliki potensi 1,60 ton/ha dengan ukuran biji 10 $\mathrm{g} / 100$ biji (biji sedang) dan umur panen 87 hari (umur sedang) (Balitkabi, 2008). Varietas Detam I dan Detam II merupakan kedelai silangan dari varietas impor Taiwan dengan varietas lokal yaitu Kawi dan Wilis hitam nasional. Produktivitas kedua varietas ini $300 \%$ lebih tinggi dibandingkan rata-rata produksi kedelai.Varietas ini dirilis pada tahun 2008 (Balitkabi, 2011). Penelitian ini bertujuan untuk mendapatkan varietas kedelai yang mampu tumbuh baik dan berproduksi tinggi di lahan pesisir yang diberi perlakuan biokompos.

\section{METODE}

Penelitian ini dilaksanakan di Kelurahan Beringin Raya, Kecamatan Muara Bangkahulu, Kota Bengkulu. Rancangan percobaan yang digunakan dalam penelitian ini yaitu Rancangan Acak Kelompok Lengkap (RAKL) faktor tunggal dengan perlakuan empat varietas kedelai (Grobogan, Wilis, Detam I, dan Detam II). Masing-masing perlakuan diulang sebanyak lima kali sehingga terdapat 20 satuan percobaan.

Persiapan lahan. Dimulai dengan pembersihan gulma dan pengolahan tanah 
dengan menggunakan cangkul kemudian dibuat petakan berukuran $1,5 \mathrm{~m}$ x $3 \mathrm{~m}$. Jarak antar petak $50 \mathrm{~cm}$. Pemberian 10 ton/ha kompos kulit kopi $(4,5 \mathrm{~kg} /$ petak) dilakukan saat persiapan lahan. Penanaman dimulai dengan membuat lubang tanam menggunakan tugal yang terbuat dari kayu dengan kedalaman $\pm 5 \mathrm{~cm}$ dan jarak tanam $30 \mathrm{~cm} \times 30 \mathrm{~cm}$ sehingga dalam satu petakan terdapat 50 tanaman. Setelah penugalan, lubang tanam diberi Carbofuran sebanyak 5-8 butir/lubang tanam. Setiap lubang tanam dimasukkan 2 benih kedelai, kemudian lubang tanam ditutup kembali dengan tanah. Pemupukan dilakukan pada saat penanaman dengan cara ditabur pada alur di antara barisan lubang tanam kedelai, kemudian pupuk ditaburkan secara merata pada alur tersebut. Dalam satu petak terdapat empat alur pupuk dengan dosis pupuk Urea 45 $\mathrm{g} /$ petak (50 kg/ha), SP36 $45 \mathrm{~g} /$ petak (50 $\mathrm{kg} / \mathrm{ha}$ ), $\mathrm{KCl} 45 \mathrm{~g} /$ petak (50 kg/ha).

Pemeliharaan. Proses ini meliputi penyulaman, penyiangan, penjarangan, penyiraman, pembubunan, dan pengendalian Organisme Pengganggu Tanaman (OPT). Sedangkan panen kacang kedelai dilakukan dua kali yaitu pada saat fase vegetatif dan fase generatif. Pemanenan pada fase vegetatif dilakukan saat $\pm 10 \%$ tanaman sudah berbunga dan pemanenan fase generatif dilakukan saat 95\% polong pada satu tanaman telah berwarna coklat tua dan kering, daun menguning dan batang mulai mengering.
Pengamatan. Dilakukan pemilihan terhadap 10 tanaman sampel $(20 \%)$ dari 50 tanaman/petak yaitu 5 sampel fase vegetatif dan 5 sampel fase generatif. Tanaman sampel ditentukan secara acak pada setiap petakan. Variabel yang diamati dalam penelitian ini yaitu pada fase vegetatif meliputi tinggi tanaman, bobot kering, serapan $\mathrm{K}$ dan serapan $\mathrm{N}$, sedangkan variabel yang diamati pada fase generatif meliputi umur berbunga, jumlah polong bernas per tanaman, jumlah biji per tanaman, bobot biji per tanaman, dan bobot 100 biji.

Analisis Data. Data yang diperoleh akan dianalisis menggunakan Analisis Varian (ANAVA) taraf 5\%. Jika terdapat beda nyata antar perlakuan maka dianalisis lanjut dengan DMRT (Duncan's Multiple Range Test) taraf $5 \%$.

\section{HASIL}

Berdasarkan analisis keragaman (Tabel 1) diketahui bahwa varietas berpengaruh sangat nyata terhadap variabel serapan $\mathrm{K}$, serta berpengaruh nyata terhadap tinggi tanaman, bobot kering tanaman, persen polong bernas per tanaman, jumlah biji per tanaman, berat biji per tanaman, dan bobot 100 biji. Sedangkan pada variabel umur berbunga, dan serapan $\mathrm{N}$ perbedaan varietas memberikan pengaruh yang tidak nyata.

Tabel 1. Data analisis seluruh variabel

\begin{tabular}{cc}
\hline Variabel Penelitian & F-hitung \\
\hline Tinggi Tanaman & $4,71^{*}$ \\
\hline Umur Berbunga & $2,67^{\text {ns }}$ \\
\hline Bobot Kering Tanaman & $4,75^{*}$ \\
\hline Serapan K & $7,78^{* *}$ \\
\hline Serapan N & $3,15^{\text {ns }}$ \\
\hline Persentase Polong Bernas per Tanaman & $12,12^{*}$ \\
\hline Jumlah Biji/Tanaman & $24,88^{*}$ \\
\hline Berat Biji/Tanaman & $40,75^{*}$ \\
\hline Bobot 100 Biji & $45,62^{*}$
\end{tabular}

Ket: $*=$ berpengaruh nyata, ${ }^{\mathrm{ns}}=$ Non-significant

Hasil penelitian menunjukkan bahwa perbedaan varietas berpengaruh tidak nyata terhadap $\mathrm{N}$-jaringan dan serapan $\mathrm{N}$. Hal ini menunjukkan bahwa masing-masing varietas memiliki kemampuan relatif sama dalam penyerapan unsur hara N. Tinggi tanaman pada varietas Wilis adalah $63,13 \mathrm{~cm}$ lebih tinggi $20 \%$ dari varietas Detam I yaitu 41,25 
$\mathrm{cm}$. Hal ini diduga karena varietas Wilis, Detam II dan Grobogan mempunyai daya adaptasi dengan lingkungan lebih baik dari varietas Detam I. Perbedaan adaptasi terhadap lingkungan terjadi karena adanya perbedaan keragaman genetik yang dimiliki oleh masingmasing varietas (Tabel 2). Varietas Grobogan menghasilkan serapan $\mathrm{K}$ tertinggi yaitu $0,22 \mathrm{~g}$. Hal ini menunjukkan bahwa akumulasi unsur
$\mathrm{K}$ pada jaringan tanaman varietas Grobogan lebih tinggi dari varietas lainnya. Sementara itu varietas Wilis menghasilkan persen jumlah polong bernas/tanaman tertinggi, jumlah biji per tanaman terbanyak, dan bobot biji per tanaman terberat. Persentase polong bernas per tanaman varietas Wilis $(91,12 \%)$ lebih tinggi $4,4 \%$ dari varietas Detam II $(83,40 \%)$ (Tabel $3)$.

Tabel 2. Rerata hasil tinggi tanaman, bobot kering tanaman, N-jaringan, dan serapan $\mathrm{N}$

\begin{tabular}{lcccc}
\multicolumn{1}{c}{ Varietas } & Tinggi Tanaman $(\mathbf{c m})$ & Bobot Kering Tanaman $(\mathbf{g})$ & Serapan K $(\mathbf{g})$ & Serapan N $(\mathbf{g})$ \\
\hline Grobogan & $54,29 \mathrm{ab}$ & $7,92 \mathrm{a}$ & $0,22 \mathrm{a}$ & 0,29 \\
\hline Wilis & $63,13 \mathrm{a}$ & $5,09 \mathrm{~b}$ & $0,12 \mathrm{~b}$ & 0,19 \\
\hline Detam I & $41,25 \mathrm{~b}$ & $5,86 \mathrm{~b}$ & $0,14 \mathrm{~b}$ & 0,22 \\
\hline Detam II & $59,68 \mathrm{a}$ & $5,74 \mathrm{~b}$ & $0,13 \mathrm{~b}$ & 0,21
\end{tabular}

Ket: Angka-angka yang diikuti oleh huruf yang berbeda pada kolom yang sama berbeda nyata pada DMRT 5\%

Tabel 3. Rerata hasil umur berbunga, persentase polong bernas/tanaman, jumlah biji/tanaman, bobot biji/tanaman dan bobot 100 biji

\begin{tabular}{lccccc}
\hline Varietas & $\begin{array}{c}\text { Umur } \\
\text { Berbunga } \\
\text { (hari) }\end{array}$ & $\begin{array}{c}\text { Persentase Polong } \\
\text { Bernas/Tanaman (\%) }\end{array}$ & $\begin{array}{c}\text { Jumlah Biji/ } \\
\text { Tanaman (buah) }\end{array}$ & $\begin{array}{c}\text { Bobot } \\
\text { Biji/Tanaman } \\
(\mathbf{g})\end{array}$ & $\begin{array}{c}\text { Bobot 100 } \\
\text { Biji }(\mathbf{g})\end{array}$ \\
\hline Grobogan & 38,00 & $86,06 \mathrm{~b}$ & $126,76 \mathrm{c}$ & $21,55 \mathrm{~b}$ & $18,00 \mathrm{a}$ \\
\hline Wilis & 42,20 & $91,12 \mathrm{a}$ & $249,56 \mathrm{a}$ & $30,92 \mathrm{a}$ & $14,58 \mathrm{~b}$ \\
\hline Detam I & 48,00 & $84,70 \mathrm{~b}$ & $204,15 \mathrm{~b}$ & $13,90 \mathrm{c}$ & $12,10 \mathrm{c}$ \\
\hline Detam II & 41,40 & $83,40 \mathrm{~b}$ & $143,90 \mathrm{c}$ & $15,50 \mathrm{c}$ & $12,85 \mathrm{c}$ \\
\hline
\end{tabular}

Ket: Angka-angka yang diikuti oleh huruf yang berbeda pada kolom yang sama berbeda nyata pada DMRT 5\%

\section{PEMBAHASAN}

Sejalan dengan hasil penelitian Ghulamahdi $d k k$. (2006) bahwa varietas kedelai (Wilis dan Bromo) memiliki kemampuan yang sama dalam menyerap unsur $\mathrm{N}$ sehingga secara statistik berpengaruh tidak nyata. Selain itu, rendahnya $\mathrm{N}$ yang tersedia di tanah menyebabkan tanaman menyerap $\mathrm{N}$ dalam jumlah sedikit. Rendahnya $\mathrm{N}$ kemungkinan disebabkan oleh tekstur tanah terbesar pada lahan penelitian ini yaitu pasir sebesar $89,2 \%$. Oleh karena itu masih terjadi pencucian hara walaupun telah diberi bahan organik sehingga $\mathrm{N}$ yang tersedia untuk tanaman masih rendah. Unsur $\mathrm{N}$ yang tersedia dalam tanah adalah dalam bentuk $\mathrm{NO}_{3}^{-}$dan $\mathrm{NH}_{4}^{+}$(Saptiningsih, 2007). $\mathrm{NO}_{3}^{-}$merupakan anion yang tidak terikat oleh koloid tanah.

Pertumbuhan tinggi tanaman dipengaruhi oleh interaksi antara genetik dan lingkungan tumbuhnya. Respon genotip terhadap faktor lingkungan terlihat dalam penampilan fenotip dari tanaman bersangkutan dan salah satunya dapat dilihat dari pertumbuhannya (Bakhtiar $d k k ., 2014$; Darliah $d k k ., 2001)$. Nilahayati dan Putri (2015) menambahkan bahwa suatu varietas tanaman yang ditanam pada kondisi lingkungan yang berbeda akan memberikan respon fenotip yang berbeda pula.

Varietas Grobogan memiliki bobot kering tanaman terberat yang berbeda nyata dengan ketiga varietas lainnya, sedangkan bobot kering tanaman teringan adalah varietas Wilis yang tidak berbeda nyata dengan varietas Detam I dan Detam II. Bobot kering tanaman varietas Grobogan $(7,92 \mathrm{~g})$ diikuti oleh varietas Detam I $(5,86 \mathrm{~g})$, Detam II $(5,74 \mathrm{~g})$ dan Wilis $(5,09 \mathrm{~g})$. Bobot kering tanaman varietas Grobogan 7,92 $\mathrm{g}$ lebih berat 21\% dari bobot kering tanaman varietas Wilis yaitu 5,09 g. Hal ini karena Varietas Grobogan memiliki serapan $\mathrm{N}$ lebih tinggi dari varietas lainnya. Sesuai dengan pendapat Liferdi dan Poerwanto (2010) bahwa semakin berat kering tanaman 
maka tanaman semakin banyak pula menyerap unsur $\mathrm{N}$.

Bobot kering tanaman erat kaitannya dengan serapan K. Semakin tinggi serapan akan menghasilkan bobot kering tanaman semakin tinggi. Menurut Noaman (2004), unsur $\mathrm{K}$ merupakan salah satu unsur hara anti salinitas selain unsur $\mathrm{N}$, karena unsur $\mathrm{K}$ mempunyai peranan dalam mekanisme pengaturan osmotik dalam sel, dan stres osmosis merupakan pengaruh merugikan dari salinitas pada tanaman yang tidak toleran selain toksisitas $\mathrm{Na}+$ atau $\mathrm{Cl}$.

Perbedaan jumlah polong/tanaman merupakan akibat dari adanya variasi dalam jumlah bunga pada awal pembentukannya dan tingkat keguguran organ reproduksinya sehingga hasil panen terutama ditentukan oleh jumlah polong yang dapat dipertahankan oleh tanaman. Selain itu, faktor genetik juga mempengaruhi jumlah polong bernas dari varietas yang ditanam (Muhuria, 2007; Wirnas $d k k .$, 2006).

Jumlah biji/tanaman varietas Wilis (249,56 biji) lebih tinggi $32 \%$ dari varietas Grobogan (126,76 biji). Hal ini diduga karena dipengaruhi oleh genotip dan keadaan lingkungan tumbuh tanaman. Bobot biji/tanaman yang dihasilkan varietas Wilis yaitu 30,92 g diikuti oleh varietas Grobogan $(21,55 \mathrm{~g})$, Detam II $(15,50 \mathrm{~g})$ dan Detam I $(13,90 \mathrm{~g})$. Bobot biji/tanaman varietas Wilis $30,92 \mathrm{~g}$ lebih berat $37 \%$ dari bobot biji/ tanaman varietas Detam I yaitu $13,90 \mathrm{~g}$. Hal ini terjadi karena adanya perbedaan ukuran biji pada masing-masing varietas. Produksi biji juga ditentukan oleh ukuran biji. Selain itu, setiap varietas memiliki produksi yang berbeda-beda karena memiliki keunggulan genetis yang berbeda-beda pula (Sulastiningsih, 2013; Soegito dan Arifin, 2004).

Varietas Grobogan memiliki bobot 100 biji tertinggi yang berbeda nyata terhadap tiga varietas lainnya, sedangkan bobot terendah yaitu varietas Detam I yang tidak berbeda nyata terhadap varietas Detam II dan berbeda nyata terhadap varietas Wilis. Bobot 100 biji varietas Grobogan 18,00 g lebih berat 19\% dari bobot 100 biji varietas Detam I yaitu 12,10 g.
Hal ini menunjukkan bahwa bobot biji tidak hanya dipengaruhi oleh jumlah biji tetapi dipengaruhi oleh ukuran biji. Bakar dan Chairunas (2012) melaporkan bahwa varietas Grobogan memiliki ukuran biji yang besar. Semakin besar ukuran biji, maka bobot 100 biji akan semakin tinggi (Rozison $d k k ., 2012$ ).

\section{KESIMPULAN}

Berdasarkan hasil penelitian dapat disimpulkan bahwa varietas Wilis menghasilkan tinggi tanaman tertinggi yaitu $63,13 \mathrm{~cm}$, persentase polong bernas/tanaman tertinggi yaitu $91,12 \%$, jumlah biji/tanaman terbanyak yaitu 249,56 buah, bobot biji/ tanaman terberat yaitu 30,92 g. Sedangkan Grobogan yang menghasilkan bobot kering tanaman terberat yaitu $7,92 \mathrm{~g}$, serapan $\mathrm{K}$ tertinggi yaitu $0,22 \mathrm{~g}$ dan bobot 100 biji tertinggi yaitu $18,00 \mathrm{~g}$. Dengan demikian, varietas Wilis dan Grobogan memiliki tingkat adaptasi lebih tinggi dari varietas Detam I dan Detam II.

\section{DAFTAR PUSTAKA}

Bakar BA dan Chairunas. 2012. Kajian Adaptasi Beberapa Varietas Unggul Baru Kedelai di Provinsi Aceh. Prosiding Seminar Hasil Penelitian Tanaman Aneka Kacang dan Umbi. 15 November 2011. Bogor: Pusat Penelitian dan Pengembangan Tanaman Pangan. hal. 126-123.

Bakhtiar, Hidayat T, Jufri Y, Safriati S. 2014. Keragaan Pertumbuhan dan Komponen Hasil Beberapa Varietas Unggul Kedelai di Aceh Besar. J. Floratek. vol 9(2): 4652.

https://doi.org/10.24815/floratek.v9i2.19 99.

Balitkabi. 2008. Deskripsi Varietas Unggul Kacang-kacangan dan Umbi-umbian. Malang: Balai Penelitian Tanaman Kacang-Kacangan dan Umbi-Umbian. http://balitkabi.litbang.pertanian.go.id/. Diakses Desember 2017.

Balitkabi. 2011. Varietas Unggul Kedelai. Edisi Khusus Penas XIII. Malang: Balai Penelitian Tanaman Kacang-Kacangan dan
Umbi-Umbian. 
http://balitkabi.litbang.pertanian.go.id/.

Diakses Desember 2017.

Barus J. 2013. Potensi Pengembangan dan Budidaya Kedelai pada Lahan Suboptimal di Lampung. Prosiding Seminar Nasional Lahan Suboptimal. 20-21 September 2013. Palembang: Universitas Sriwijaya. ISBN 979-587-501-9. hal 1-12.

Berlian Z, Syarifah S, Sari DS. 2015. Pengaruh

Pemberian Limbah Kulit Kopi (Coffea robusta L.) terhadap Pertumbuhan Cabai Keriting (Capsicum annum L.). Jurnal Biota. vol 1(1):22-32.

Caldwell CR, Britz SJ, Mirecki RM. 2005.

Effect of Temperature, Elevated Carbon Dioxide, and Drought during Seed Development on the Isoflavone Content of Dwarf Soybean [Glycine max (L.) Merrill] Grown in Controlled Environments. J. Agric. Food Chem. vol 53(4):

1125-1129. https://doi.org/10.1021/jf0355351.

Cornell SE, Jickells TD, Cape JN, Rowland AP. Duce RA. 2003. Organic Nitrogen Deposition on Land and Coastal Environments: A Review of Methods and Data. Atmospheric Environment. vol 37(16): 2173-2191. https://doi.org/10.1016/S13522310(03)00133-X.

Darliah IS, de Vress DP, Handayani W, Herawati T dan Sutater T. 2001. Variabilitas Genetik, Heritabilitas dan Penampilan Fenotipik 18 Klon Mawar di Cipanas. J. Hort. vol 11(3): 148-154.

Ghulamahdi M, Aziz SA, Melati M, Dewi N, Rais SA. 2006. Aktivitas Nitrogenase, Serapan Hara dan Pertumbuhan Dua Varietas Kedelai Pada Kondisi Jenuh Air dan Kering. Jurnal Agronomi Indonesia. vol 34 (1): 32-38. http://dx.doi.org/10.24831/jai.v34i1.1272.

Hartman GL, West ED, Herman TK. 2011. Crops that feed the World 2. Soybeanworldwide production, use, and constraints caused by pathogens and pests. Food Security. vol 3(1): 5-17.

Kementerian Pertanian. 2015. Produksi Kedelai Menurut Provinsi. http://www.litbang.pertanian.go.id/.

Diakses Desember 2017.
Lasabuda R. 2013. Pembangunan Wilayah Pesisir Dan Lautan Dalam Perspektif Negara Kepulauan Republik Indonesia. Jurnal Ilmiah Platax. vol. I-2: 92-101.

Liferdi L dan Poerwanto R. 2010. Korelasi Konsentrasi Hara Nitrogen Daun dengan Sifat Kimia Tanah dan Produksi Manggis. J. Hort. vol 21(1): 14-23. http://dx.doi.org/10.21082/jhort.v21n1.20 11.p14-23.

Mellawati J. 2002. Reduksi Biologi dari Limbah Pabrik Kopi Menggunakan Cacing Tanah Eisenia foetida. Buletin Kimia. vol (2): 28-34.

Muhuria L, Sopandie D, Khumaida N, Trikoesoemaningtyas, Darusman LK, Jane T. 2007. Mekanisme fisiologi dan pewarisan sifat toleransi kedelai (Glycine max (L) Merrill) terhadap intensitas cahaya rendah. [Disertasi]. Bogor: Institut Pertanian Bogor.

Nilahayati dan Putri LAP. 2015. Evaluasi Keragaman Karakter Fenitope Beberapa Varietas Kedelai (Glycine max L.) di Daerah Aceh Utara. J. Floratek. vol 10: 36-45. https://doi.org/10.24815/floratek.v10i1.2 328.

Noaman MN. 2004. Effects of Potassium and Nitrogen Fertilizers on the Growth and Biomass of Some Halophytes Grown under High Level of Salinity. J. Agron. vol 3(1): 25-30. http://dx.doi.org/10.3923/ja.2004.25.30.

Pemerintah Provinsi Bengkulu. 2015. Geologi Pemerintah Provinsi Bengkulu. http://bengkuluprov.go.id/. Diakses Desember 2017.

Rajiman, Yudono P, Sulistyaningsih E, Hanudin E, 2008. Pengaruh Pembenah Tanah Terhadap Sifat Fisika Tanah dan Hasil Bawang Merah Pada Lahan Pasir Pantai Bugel Kabupaten Kulon Progo. J. Agrin. vol 12(1): 67-77. http://dx.doi.org/10.20884/1.agrin.2008.1 2.1.80.

Rozison, Suryati D, Ganefianti DW. 2012. Karakterisasi Galur-Galur Harapan Kedelai Yang Efisien Menggunakan 
Fosfor. [Tesis]. Bengkulu: Fakultas Pertanian, Universitas Bengkulu.

Saptiningsih E. 2007. Peningkatan Produktivitas Tanah Pasir Untuk Pertumbuhan Tanaman Kedelai dengan Inokulasi Mikorhiza dan Rhizobium. Bioma: Berkala Ilmiah Biologi. vol 9(2): 58-61. http://dx.doi.org/10.14710/bioma.9.2.5861.

Shi Z, Li Y, Wang RC, Makeschine F. 2005. Assessment of Temporal and Spatial Variability of Soil Salinity in a Coastal Saline Field. Environmental Geology. vol 48(2): 171-178. http://dx.doi.org/10.1007/s00254-0050035-x.

Sahputra A, Barus A, Sipayung R. 2013. Pertumbuhan dan Produksi Bawang Merah (Allium ascalonicum L.) Terhadap Pemberian Kompos Kulit Kopi dan Pupuk Organik Cair. Jurnal Online Agroekoteknologi. vol 2(1): 26-35.

Simanjuntak A, Lahay RR, Purba E.2013. Respon Pertumbuhan dan Produksi Bawang Merah (Allium ascalonicum L.) Terhadap Pemberian Pupuk NPK dan Kompos Kulit Buah Kopi. Jurnal Online Agroekoteknologi. vol 1(3): 362-373.

Simarmata R dan Sukiman H. 2015. Efikasi Burkholderia cepacia GL3 dalam Memacu Pertumbuhan Tanaman Kedelai (Glycine max). Biogenesis. vol 3(2): 7680. https://doi.org/10.24252/bio.v3i2.930.

Sitorus SRP, Kusumastuti E. Badri LN. 2008. Karakteristik dan Teknik Rehabilitasi Lahan Pasca Penambangan Timah di Pulau Bangka dan Singkep. Jurnal Tanah dan Iklim. vol 27:57-74.
Soegito dan Arifin. 2004. Pemurnian dan Perbanyakan Benih Penjenis Kedelai. Malang: Balai Penelitian Tanaman Kacang-Kacangan dan Umbi-Umbian. http://balitkabi.litbang.pertanian.go.id/. Diakses Desember 2017.

Sulastiningsih NWH, Suharsono, Aris T. 2013. Uji Daya Hasil Beberapa Galur Kedelai (Glycine max L. Merr) di Mataram pada Dua Musim Tanam. [Tesis]. Bogor: Institut Pertanian Bogor.

Sumardi. 2008. Prinsip Silvikultur Reforestasi dalam Rehabilitasi Formasi Gumuk Pasir di Kawasan Pantai Kebumen. Prosiding Seminar Nasional Silvikultur Rehabilitasi Lahan: Pengembangan Strategi untuk Mengendalikan Tingginya Laju Degradasi Hutan. 24-25 November 2008. Yogyakarta: Fakultas Kehutanan, Universitas Gadjah Mada. hal. 58-65.

Sunardi dan Sarjono Y. 2007. Penentuan Kandungan Unsur Makro pada Lahan Pasir Pantai Samas Bantul dengan Metode Analisis Aktivasi Neutron (AAN). Prosiding PPI-PDIPTN. 10 Juli 2007. Yogyakarta: Pusat Teknologi Akselerator dan Proses Bahan, Badan Tenaga Nuklir Nasional (BATAN). hal. 123-129.

Wirnas D, Widodo I, Sobir, Trikoesoemaningtyas, Sopandie D. 2006. Pemilihan Karakter Agronomi untuk Menyusun Indeks Seleksi pada 11 Populasi Kedelai Generasi F6. Jurnal Agronomi Indonesia. vol 34(1): 19-24. http://dx.doi.org/10.24831/jai.v34i1.1270

Yuwono NW. 2009. Membangun Kesuburan di Lahan Marginal. Ilmu Tanah dan Lingkungan. vol 9(2): 137-141. 